\title{
Nomenclatural Notes on Callitriche (Callitrichaceae) in North America
}

\author{
Richard V. Lansdown \\ 45 The Bridle, Stroud, Gloucestershire GL5 4SQ, United Kingdom. \\ rlansdown@ardeola.demon.co.uk
}

Abstract. Taxonomic review is provided for taxa of Callitriche L. (Callitrichaceae) occurring in North America. One new species, C. stenoptera Lansdown, is described from Arizona in the United States, and the following names are lectotypified: $C$. anceps Fernald, C. drummondii Hegelmaier, C. hermaphroditica L. var. bicarpellaris (Fenley ex Jepson) H. Mason, $C$. longipedunculata Morong, $C$. marginata Torrey, $C$. nuttallii Torrey, C. sepulta S. Watson, and $C$. stenocarpa Hegelmaier.

Key words: Callitrichaceae, Callitriche, North America.

Taxa in Callitriche L. (Callitrichaceae) are monoecious, or in a single case $(C$. petriei $\mathrm{R}$. Mason subsp. petriei), dioecious, the flowers are axillary and usually solitary, but may occur in various combinations in the same axil; the perianth is absent, but a subtending pair of bracts may be present in some species. The fruits are schizocarps, separating into four mericarps that are dry, winged or not, with wings from the inner fruit layer. Due to their small size and reduced nature, it can be difficult to find reliable characters by which to distinguish Callitriche taxa. The presence or absence of a wing on the outer margins of the fruit is the most important character used both taxonomically and in identification. Work on the European members of the genus (e.g., Schotsman, 1967; Lansdown, 2006) has shown that while the outer layer of cells may at times resemble a wing, the wing is actually formed of processes arising from the testa; these processes usually define the walls of cells and may be linked to complex fibrils crossing the faces of the cells (Lansdown, 2008). The wing has played such a significant role in Callitriche taxonomy that a number of taxa, such as the subspecies of $C$. truncata Gussone, are defined largely by the presence or absence of a wing. As employed here, therefore, the term wing applies only to a structure arising from and of a clearly different structure to the testa.

Taxonomic work on North American Callitriche has been based almost exclusively on herbarium material. The study of dried fruit in Callitriche is complicated, at least in part, because of the response of fruit to preparation as herbarium specimens. Immature fruit are usually soft and tend to compress, and there is a stage at which fruit that have reached their full size but not hardened will distort on pressing and appear larger than mature fruit. In most cases, this distortion also makes it impossible to study details of the wing. In addition, until fruit are absolutely mature, the drying process can make up to quite a broad band of marginal cells appear translucent in contrast to the cells of the testa and can give the appearance of a wing. A further problem arises when fresh fruits are swollen (as is the case in C. peploides Nuttall), but this is reduced on drying to a strumose base to each mericarp. Dried material of $C$. peploides var. peploides can resemble $C$. palustris L., but the confusion would be unlikely to occur in relation to fresh material as the latter does not have swollen fruit. The styles and bracts associated with immature fruit are fragile and, depending on the quality of pressing and the age and degree of use of a specimen, can either remain attached or be lost, making it difficult to establish whether or not these characters are naturally persistent or caducous. Most herbarium specimens of Callitriche worldwide, not just in North America, are more than 100 years old and few are in good enough condition to provide reliable taxonomic data.

In preparing the treatment of Callitriche for the Flora of North America, more than 1000 herbarium specimens were studied from an area in the Americas extending from Alaska east to Greenland and south to Mexico from the following herbaria: ALA, BM, F, JEPS, K, LE, MICH, MO, ORE, PE, TAMU, UBC, UC, V, and WTU. Fresh material from 103 live populations of 12 taxa was studied in Alaska, California, Missouri, Oregon, Texas, Washington, and British Columbia. All descriptive and biometric data employed here are based on specimens collected in North America. One new species was identified: $C$. stenoptera Lansdown, occurring in the western United States and throughout southern Canada, but previously overlooked as $C$. hermaphroditica $\mathrm{L}$.

\section{Key to the Caluttriche Species Found in North America}

la. Fruit unwinged, i.e., lacking processes arising from the testa .......................

lb. Fruit winged, even if only narrowly at the apex... 5 
2a. Mericarps swollen or (in dried material) with the bases swollen at the point where they meet, such that there is no evident flat face... C. peploides Nuttall

2b. Mericarps without swollen bases, at least one face

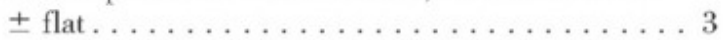

3a. Fruits longer than wide; mericarps not divergent at apex................. palustris L.

3b. Fruits as wide as or wider than long; mericarps divergent at apex .............. 4

4a. Fruits $(0.6-) 0.7-0.8(-1) \mathrm{mm}$ wide $\ldots \ldots \ldots \ldots$ ....... C. heterophylla Pursh var. heterophylla

4b. Fruits (0.8-)0.9-1.1(-1.2) mm wide. . . . . . ........ C. heterophylla Pursh var. bolanderi . . . . . . . . . . . . (Hegelmaier) Fassett

5a. Fruit winged only at apex $\ldots \ldots \ldots \ldots 6$

5b. Fruit winged throughout. . . . . . . . . 9

6a. Fruits pedunculate with peduncles $\pm 0.2 \mathrm{~mm}$ long; fruits much wider than long. . . C. terrestris Rafinesque

6b. Fruits sessile or subsessile; fruits longer than or as long as wide $\ldots \ldots \ldots \ldots \ldots \ldots \ldots \ldots \ldots$

7a. Fruits longer than wide; mericarps not divergent at apex................ palustris L.

7b. Fruits as wide as or wider than long; mericarps

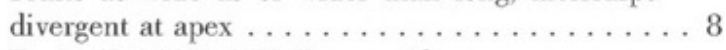

8a. Fruits (0.6-) 0.7-0.8(-1) mm wide . . . . . . ........ C. heterophylla Pursh var. heterophylla

8b. Fruits (0.8-)0.9-1.1(-1.2) mm wide... . . . . ........ C. heterophylla Pursh var. bolanderi $\ldots \ldots \ldots \ldots \ldots$. Hegelmaier) Fassett

9a. Leaf bases not joined; pollen and anthers translucent or appearing pale; no peltate scales on stem and leaves; bracts absent; leaves with a primary vein but without secondary veins . . . . . . 10

9b. Leaf bases joined by a ridge of tissue extending across the node; pollen and anthers yellow or translucent; peltate scales on stem and leaves; bracts present or caducous; leaves with a primary vein and often with secondary veins . . . . . 12

10a. Wing narrower than seed width... C. stenoptera Lansdown

$10 \mathrm{~b}$. Wing as wide as or wider than seed width . . . . 11

11a. Fruit pedunculate, wider than long . . . . . . . .............. fassettii Schotsman

11b. Fruit sessile, as wide as long ... C. hermaphroditica L.

12a. At least some fruit on peduncles $>2 \mathrm{~mm}$ long. . 13

12b. Fruit sessile or on peduncles $<2 \mathrm{~mm}$ long .... 15

13a. Fruits longer than wide; bracts present; most filaments $>2 \mathrm{~mm}$ long... C. longipedunculata Morong

13b. Fruits wider than long; bracts lacking; filaments $<$ $1 \mathrm{~mm}$ long. . . . . . . . . . . . . 14

14a. Fruits appearing flat-ended because wing curved outward, with no notch between the margins of the mericarps . . . . . . . nuttallii Torrey

14b. Fruits with a distinct notch between the margins of the mericarps........... marginata Torrey

15a. Stigma $1.5-4.5 \mathrm{~mm}$ long, reflexed and appressed to side of fruit; pollen (and therefore anthers) colorless ........ C. brutia Petagna var. hamulata . . . . . . Kützing ex W. D. J. Koch) Lansdown

15b. Stigma erect or if reflexed, then $<1 \mathrm{~mm}$, not appressed to side of fruit; pollen (and therefore anthers) yellow . . . . . . . . . . . 16

16a. Fruit $<1 \mathrm{~mm}$ long, wider than long..$\ldots \ldots \ldots$ $\ldots \ldots \ldots \ldots \ldots \ldots$. terrestris Rafinesque

16b. Fruit $>1 \mathrm{~mm}$ long, \pm as wide as long ..... 17

17a. Ripe fruit brown or grayish brown; bracts persistent; wing wide.......... C. stagnalis Scopoli 17b. Ripe fruit blackish; bracts caducous; wing narrow.............. C. trochlearis Fassett

1. Callitriche anceps Fernald, Rhodora 10: 51. 1908. TYPE: Canada. [Quebec:] W base of Table-topped Mtn., "Lac des Americains," $670 \mathrm{~m}, 1$ Aug. 1906, M. L. Fernald \& J. F. Collins 234 (lectotype, designated here, GH 48916; isotypes, K, NY 248728, NY 248729, US 60607). EPITYPE: Canada. "Stranded $3 \mathrm{dm}$ above water, margin of the uppermost lake at head of E Fork of R. Ste. Anne des Monts," 1050 m, 8 Aug. 1906, M. L. Fernald \& J. F. Collins 638 (epitype, designated here, GH 48916).

Fernald cited Fernald \& Collins 234, from "Lac des Americains, western base of Table-topped Mountain, 1 August 1906," as the type of his name Callitriche anceps. I have seen five sheets holding part of this collection and none has any mature fruit. Similarly, the scanned image of the type material in US clearly shows very small plants lacking mature fruit, although there may be mature material in the packet. Included on the holotype sheet GH 48916 as well as type material of $C$. anceps, there is material from two other collections: Fernald \& Collins 637 that also bears no mature fruit and Fernald \& Collins 638 that has mature fruits. This material was evidently considered by Fernald to be of the same taxon as the type material of $C$. anceps and agrees with the concept of $C$. anceps Fernald given by Fassett (1951: 187) and as applied by most American authors. Therefore, although it will not be possible to clarify the taxonomic status of $C$. anceps without detailed study of live populations, I have designated Fernald \& Collins 638 at GH as an epitype because of the representative presence of mature fruits.

2. Callitriche fassettii Schotsman, Acta Bot. Neerl. 15: 477. 1966. TYPE: U.S.A. Oregon: "in small ponds near Dalles City, Oregon," 4 May 1898, W. M. Suksdorf 2746 (holotype, L 910185605 not seen; isotypes, DS not seen, GH, MO, US not seen, WTU).

Callitriche hermaphroditica L. var. bicarpellaris (Fenley ex Jepson) H. Mason, Fl. Marshes Calif.: 557. 1957, syn. nov. C. autumnalis L. var. bicarpellaris Fenley ex Jepson, Fl. Calif. 2: 436. 1936. TYPE: U.S.A. California: San Joaquin Co., $4 \mathrm{mi}$. N of Clementes, 3 May 1928, H. Mason 4445 (lectotype, designated here, UC 570781; isotype, GH 48919).

Callitriche autumnalis var. bicarpellaris was described by Jepson in 1936 (based on an unpublished manuscript account of 1932 by Kittie Fenley), who cited three collections from California, the type as cited above and two that Fenley collected herself west 
of Santa Rosa (Fenley 561 and 562). Apparently unfamiliar with this material, in 1966 Schotsman named $C$. fassettii based on material from pools near The Dalles, on the northern border of Oregon. Comparison of material from both types shows clearly that $C$. autumnalis var. bicarpellaris and $C$. fassettii represent the same taxon and that although they are closely related to $C$. hermaphroditica $\mathrm{L}$., they also show consistent and striking differences from it. Inaccurately listed as a synonym of $C$. hermaphroditica in Lansdown (2006), the name C. fassettii is retained for this taxon and the name $C$. autumnalis var. bicarpellaris is reduced to synonymy of this name.

3. Callitriche longipedunculata Morong, Bull. Torrey Bot. Club 18: 236. 1891. TYPE: U.S.A. California: San Diego, Mesas, 8 May 1884, C. R. Orcutt s.n. (lectotype, designated here, NY 248733 [3 of the 4 specimens, the 2 upper and 1 left-hand of the lower specimens on sheet]).

Callitriche longipedunculata was described by Thomas Morong (1891) based on material sent to him by C. R. Orcutt. The letter written in response to receipt of the material is included with the isotype in UC. In it, Morong states "It is not C. marginata Torrey, which is a very different species, but one not hitherto described and which I have named $C$. longipedunculata and expect soon to publish under that name. Its nearest ally is $C$. muscoides Goldbach found at Constantinople. I return by mail the specimen and label as you desired." However, the UC material is entirely composed of $C$. marginata Torrey. Similarly, a sheet in US bears the note "This is not $C$. marginata Torrey but an undescribed species which I have named, M," which I presume to be by Morong; however, this, too, is entirely composed of $C$. marginata Torrey. The only one of eight isotypes of $C$. longipedunculata cited by Morong in 1891 that includes any of that species as it is currently interpreted is NY 248733 , which bears three collections of $C$. longipedunculata and one of $C$. marginata. In consideration of the mixed status of the type, according to Articles 9.2 and 9.12 of the International Code of Botanical Nomenclature (ICBN; McNeill et al., 2006), I therefore designate above three of the four samples of this species on this sheet as the lectotype.

4. Callitriche marginata Torrey, Pacific Railr. Rep. 4(5): 135. 1857. TYPE: U.S.A. [California:] Sonoma Co., "muddy places along Mark West's Creek," 30 Apr. 1854, J. M. Bigelow s.n. (lectotype, designated here, MO 1913618; isotypes, GH, K, NY, STU not seen, US not seen).
Callitriche sepulta S. Watson, Proc. Amer. Acad. Arts 14: 298. 1879, syn. nov. TYPE: U.S.A. Oregon: s.d., E. Hall 459 (lectotype, designated here, MO 1913631; isotypes, NY 248740, NY 248741).

Most sheets representing parts of the type of Callitriche marginata have parts of two collections mounted on them, one by Bigelow from "muddy places along Mark West's Creek, California" with a printed label saying "Lieut. A. W. Whipple's Exploration for a Railway Route, from the Mississippi River to the Pacific Ocean, near the 35th parallel of latitude in 1853-4. Collected by Dr. J. M. Bigelow, Surgeon and botanist to the expedition," the other simply labeled "Rev. Mr. Fitch, California." Torrey (1857) cited "Muddy places along Mark West's creek, California; April 30. Upper California; Rev. A. Fitch," combining text from both collections and causing confusion. The MO 1913618 sheet is a mixed specimen that includes material collected by Fitch that is ex. herb. Torrey as well as material collected by J. M. Bigelow annotated "co-type" by N. C. Fassett. According to Art. 9.12 of the ICBN (McNeill et al., 2006), the material collected by J. M. Bigelow on sheet MO 1913618 is designated here as the lectotype.

5. Callitriche nuttallii Torrey, Pacific Railr. Rep. 4(5): 135. 1857. Replaced name: Callitriche pedunculosa Nuttall, Trans. Amer. Philos. Soc., ser. 2, 5: 140. [Jan.] 1835, non Callitriche pedunculata DC., 1805. TYPE: U.S.A. Louisiana: s.d., J. Hale s.n. (lectotype, designated here, NY 465074; isotypes, GH 219782, MO 1913611, NY 465070).

From his description, it is clear that by his Callitriche pedunculosa, Nuttall intended a terrestrial Callitriche with pedunculate fruit that occurred in Arkansas. This could equally refer to $C$. terrestris Rafinesque, which is more abundant and widespread than $C$. nuttallii Torrey in the state. Nuttall (1835) did not list any specimens in his description, nor did Torrey (1857). Hegelmaier (1867) listed "Arkansas, Nuttall 1835; Louisiana, J. Hale, comm. Engelm.," the former not associated with any specimen that I have been able to locate, but the latter represented by specimens in GH, MO, and NY. Of these specimens, only NY 465074 is not part of a mixed collection and includes "Louisiana" and "J. Hale" on the label. The lectotype chosen above maintains $C$. nuttallii in its current interpretation.

Torrey (1857) described Callitriche marginata as "A well characterized species, resembling $C$. nuttallii; nob. [us, presumably referring to himself and Nuttall] (C. pedunculosa, Nutt. in Trans. Amer. Phil. Soc. n. ser. 5, p. 140; not of Arnott, nor C. pedunculata DC.)." 
He correctly considered $C$. pedunculosa to be a homonym of $C$. pedunculata DC.

6. Callitriche palustris L., Sp. Pl. 2: 969. 1753. TYPE: [Europe.] "Habitat in Europae fossis paludibus" (lectotype, designated by Lansdown \& Jarvis, 2004: 169, LINN 13.1 [lowermost 3 specimens on sheet]).

Callitriche stenocarpa Hegelmaier, Verh. Bot. Ver. Prov. Brandenburg 10: 114, 1868, syn. nov. Callitriche palustris var. stenocarpa (Hegelmaier) Jepson, Man. Fl. Pl. Calif. (Jepson) 1925, syn. nov. TYPE: U.S.A. California: San Mateo Co., Searsville, 1864, H. N. Bolander 78 (lectotype, designated here, MO 1913617; isotype, GH 48922).

Callitriche palustris var. verna (L.) Fenley ex Jepson, Fl. Calif. 2: 435. 1936, syn. nov. Basionym: Callitriche verna L., Fl. Suec. (ed. 2): 2 [Oct.] 1755. TYPE: [Europe.] (lectotype, designated by Lansdown \& Jarvis, 2004: 171, LINN 13.2).

Fassett (1951: 210) stated that "Individuals with fruits nearly sessile or with some of them so have been treated as Callitriche stenocarpa Hegelm." and noted that the two collections cited by Hegelmaier (1868) represent "a sorry mixture of C. verna, C. heterophylla, and $C$. marginata." Fassett went on to assign $C$. stenocarpa to the synonymy of $C$. verna $(=C$. palustris L.). Hegelmaier (1868: 114) had earlier referred to two collections in relation to this name. The first is the type material cited above for $C$. stenocarpa and the second collection was listed as "Russian River, Ukiah, Bolander 3870," which I have not seen. Bolander 78 is a mixed collection, accurately identified by N. C. Fassett (1951: 210) as including C. palustris (as "C. verna L. emend. Kütz." and "C. palustris Am. Auct."), C. heterophylla, and C. marginata, as well as fragments of Ranunculus L. The different taxa cannot be separated, being in a single mass, but $C$. palustris represents the majority of the collection and I therefore designate this material as the lectotype for the name $C$. stenocarpa Hegelmaier, reducing it to synonymy with $C$. palustris $\mathrm{L}$.

7. Callitriche peploides Nuttall, Trans. Amer. Philos. Soc., n.s. 5: 141. 1835. TYPE: U.S.A. Arkansas: s.d., T. Nuttall s.n. (lectotype, designated by Lansdown, 2006: 115, NY 248737).

\section{7a. Callitriche peploides Nuttall var. peploides.}

Callitriche drummondii Hegelmaier, Monogr. Callitriche 60 . 1864. TYPE: U.S.A. Louisiana: Orleans Parish, New Orleans, [1832], T. Drummond s.n. (lectotype, designated here, NY 248737; isotypes, GH 48917, GH 48918).

Specimens of Callitriche peploides by Drummond labeled New Orleans appear to be represented by three collections: one unnumbered, one numbered 115 (and dated 1832), and the other numbered 108. In his account of $C$. drummondii, Hegelmaier did not cite a collection number, and therefore I interpret the type as being only those sheets without a collection number. The GH sheet has material from more than one collection of the same taxon, and I have designated the NY material as the lectotype accordingly.

Two additional varieties were described by Fassett (1951) for Callitriche peploides, with variety media and variety semialata from Guatemala and Mexico, respectively. Neither taxon occurs in the North American flora.

8. Callitriche stenoptera Lansdown, sp. nov. TYPE: U.S.A. Arizona: Apache Co., Mexican Hay Lake, 6 mi. S of AZ 260 along AZ 273 on the $\mathrm{N}$ side of the rd., Eager Quad, R28E, T7N, sec. 2, 8890 ft., 22 Sep. 1984, J. Ricketson 2106 (holotype, MO 3834806). Figure 1.

Ab omnibus Callitriches L. speciebus borealiamericanis, C. hermaphroditica L. et C. fassettii Schotsman exceptis, foliis uninerviis, caule et foliis esquamtis et polline diaphano, a $C$. hermaphroditica et $C$. fassettii fructu maturo peranguste alato differt.

Flowering plants submerged. White stems contrasting strongly with dark green of leaves. Internodes decreasing gradually from base to apex, nodes bearing flowers with short internodes appearing congested. Leaves \pm lingulate, $5.9-11.3 \times 0.3-1.1 \mathrm{~mm}$; all leaves with only 1 central vein. Flowers usually solitary or 1 pistillate and 1 staminate flower or occasionally 2 pistillate flowers in an axil; bracts absent. Filaments very short, up to $0.2 \mathrm{~mm}, \pm$ straight; anthers ca. $0.2 \times 0.2 \mathrm{~mm}$; pollen colorless; styles reflexed or strongly curved downward, eventually broken off and the stump arising below the fruit apex and appressed to the side of the fruit, 0.6-1 mm. Fruits $0.8-1.2 \times 0.9-1.3 \mathrm{~mm}$, as long as or slightly narrower than wide, grayish brown; subsessile or on peduncle $<1 \mathrm{~mm}$; wing narrow, up to $0.1 \mathrm{~mm}$ at the apex and side.

Distribution and habitat. Callitriche stenoptera occurs in Alaska, in Canada from British Columbia to Ontario and Newfoundland, from Oregon and the central states from Montana south to Arizona and east to New Mexico and north to Minnesota, but with no records known from the Dakotas.

IUCN Red List category. According to IUCN Red List criteria (IUCN, 2001), Callitriche stenoptera should be classified as Least Concern (LC). 




Figure 1. Callitriche stenoptera Lansdown. -A. Fruit. -B. Leaves. Drawn from the holotype, J. Ricketson 2106 (MO).

Etymology. The epithet stenoptera (from the Greek "stenos," meaning "narrow," and "pteron," meaning "wing") refers to the narrower wing compared to that of similar species, i.e., Callitriche hermaphroditica and C. fassettii.

Discussion. Callitriche stenoptera can be distinguished from all species of Callitriche in North America except C. hermaphroditica and C. fassettii by the colorless pollen and the lack of scales on the stem and leaves, combined with all the leaves being single-veined, relatively uniform in shape, and often tapering from the base (Fig. 1). The new species can be distinguished from $C$. hermaphroditica and $C$. fassettii by the fruit on which the wing is less than $0.1 \mathrm{~mm}$ wide, even at the fruit apex. The fibrils of $C$. stenoptera in no way resemble those of $C$. hermaphroditica or $C$. fassettii, being extremely simple.

Paratypes. S. loc., s.d., G. W. Clinton s.n. (BM), CANADA. Alberta: S of Calgary, 1941, C. L. Hitchcock \& J. S. Martin 7832 (MO); Mannville, 1927, E. H. Moss 1567
(K). British Columbia: Lake Sumass, 1958, D. Lyall s.n. (K). Manitoba: White Mud River, 1895, J. Macoun 10594 (K). Newfoundland: East Brook, St. Barbe Bay, 1925, K. M. Wiegand \& N. Hotchkiss 28643 (K); Bay of Islands, 1896, A. C. Waghorne s.n. (MO). Ontario: Lake of the Woods, Kenoa, 1924, A. B. Rendle \& R. d'Oyley Good s.n. (BM); s. loc., 1879, J. Macoun 1287 (K); O'Sullivan Lake, Geraldton, Thunder Bay District, 1954, W. K. W. Baldwin 6149 (K). Saskatchewan: Maple Creek, 1947, A. J. Breitung 4882 (MO). U.S.A. Alaska: Kotzebue-Kobuk Lowland, 1960, s. coll. (UAM). Colorado: Rocky Mtns., s.d., G. Vasey s.n. (MO). Idaho: Near Thompson Mtn., 1895, J. B. Leiberg 1604 (K, MO). Minnesota: Wheaton, Traverse, 1893, E. P. Sheldon s.n. (BM). Montana: 1905, J. W. Blankinship s.n. (BM); Helena, 1892, E. Starz s.n. (MO); Charlo, Flathead Co., 1934, C. L. Hitchcock 2487 (MO); Missoula Co., Missoula, 1937, F. A. Barkley \& J. Kramer 1917 (MO). Nebraska: Pinoes Spring, 1853, F. V. Hayden s.n. (MO). New Mexico: Bitter Creek, Taos Co., 1969, D. S. Correll \& H. B. Correll 37601 (MO). Oregon: Rocky Mtns., 1845, C. A. Geyer 6226 (K); Harney Valley, 1885, T. J. Howell s.n. (K); s. loc., 1927, M. E. Peck 15743 (K); Flathead River, s.d., C. A. Geyer s.n. (K); Deschutes River, 1981, Halse 2401 (MO). Utah: Brighton, 1898, M. E. Jones 6356 (BM, MO); Fish Lake, 1894, M. E. Jones 5781 (BM, MO); Wasatch Plateau, E of Salina, 1980, 
B. Albee 4887 (MO); Clayton Peak, Wasatch Mtns., 1903, S. G. Stokes s.n. (MO). Wyoming: Kendall, Sublette Co., 1922, E. B. Payson \& L. E. B. Payson 2933 (MO).

Acknowledgments. I am deeply grateful for the help that Peter Raven (MO) has given to me with field trips and access to specimens and the literature, which has made this study possible. I am also very grateful to Mike Gilbert $(\mathrm{K})$ for all his help and hospitality. I thank Paul Berry (MICH), Dave Boufford (HUH), Aljos Farjon (K), Peter Hoch (MO), John Kress (NMNH), Lauren Phelan (K), Tony Reznicek (MICH), Peter Stafford (BM), Nick Turland (MO), Roy Vickery (BM), and George Yatskievych (MO) for their help with organizing access to herbarium material as well as helping me in many other ways. Lowell Ahart, Ed Berg, Alan Brant, Jim Manharm, Diane Coston McLaughlin, Katie Mitchell, Monique Dubrule Reed, Bill Summers, and George Yatskievych all gave me the benefit of their knowledge and experience, as well as the pleasure of their company in the field. Bruce Baldwin, Bruce Bennet, Adolf Ceska, Andrew Doran, David Giblin, Graham Griffiths, Richard Halse, Steffi Ickert-Bond, Linda Jennings, Kim Kersh, Aaron Liston, Frank Lomer, Staci Markos, Dan Mosquin, David Murray, John Pinder-Moss, Sarah Reichard, and Barbara Wilson all provided advice, facilities, and information, for which I am deeply grateful. I am also extremely grateful to Dick Brummitt for his help with typification and nomenclature, without which I would be lost.

\section{Literature Cited}

Fassett, N. C. 1951. Callitriche in the New World. Rhodora 53: 137-155, 161-182, 185-194, 209-222.

Hegelmaier, F. 1867. Zur Systematik von Callitriche. Verh. Bot. Vereins Prov. Brandenburg 9: 1-41.

1868. Beitrag zur Kentniss der Wassersterne. Verh. Bot. Vereins Prov. Brandenburg, Vol. 10.

IUCN. 2001. IUCN Red List Categories and Criteria, Version 3.1. Prepared by the IUCN Species Survival Commission. IUCN, Gland, Switzerland, and Cambridge, United Kingdom. Lansdown, R. V. 2006. Notes on the water-starworts (Callitriche) recorded in Europe. Watsonia 26: 105-120.

. 2008. Water starworts of Europe. BSBI Handbook

No. 11. Botanical Society of the British Isles, London.

McNeill, J., F. R. Barrie, H. M. Burdet, V. Demoulin, D. L. Hawksworth, K. Marhold, D. H. Nicolson, J. Prado, P. C. Silva, J. E. Skog, J. H. Wiersema \& N. J. Turland (editors). 2006. International Code of Botanical Nomenclature (Vienna Code). Regnum Veg. 146.

Morong, T. 1891. Notes on North American Haloragaceae. Bull. Torrey Bot. Club 18: 229-246.

Nuttall, T. 1835. Collections towards a flora of the territory of Arkansas. Trans. Amer. Philos. Soc., nov. ser. 5: 141.

Schotsman, H. D. 1967. Les Callitriches: Espèces de France et taxa nouveaux d'Europe. Éditions Paul Lechevalier, Paris.

Torrey, J. 1857. No. 4, The general botanical collections. In A. Whipple, Reports of Explorations and Surveys, to Ascertain the Most Practicable and Economical Route for a Railroad from the Mississippi River to the Pacific Ocean..., Vol. 4: United States. Pacific Railroad Survey, 135. 

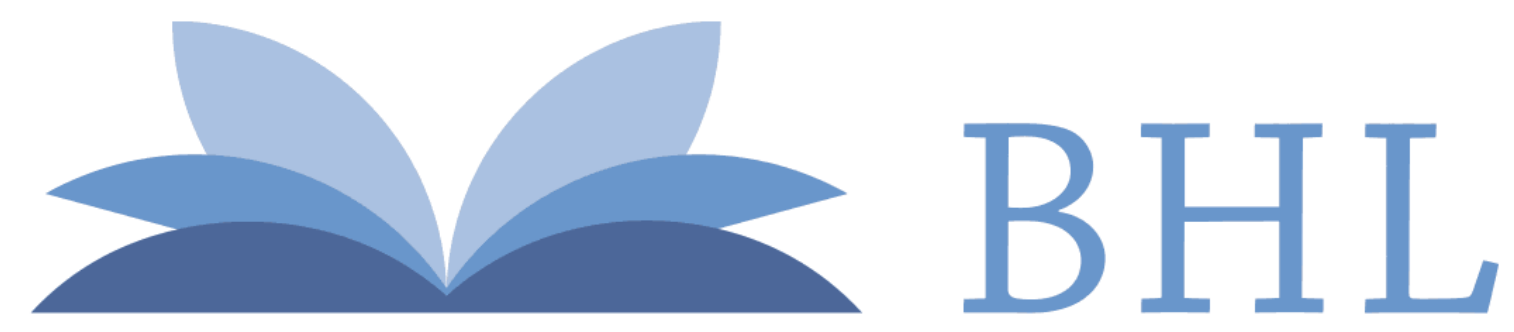

\section{Biodiversity Heritage Library}

Lansdown, Richard V. 2009. "Nomenclatural Notes on Callitriche (Callitrichaceae) in North America." Novon a journal of botanical nomenclature from the Missouri Botanical Garden 19, 364-369.

View This Item Online: https://www.biodiversitylibrary.org/item/124658

Permalink: https://www.biodiversitylibrary.org/partpdf/121935

\section{Holding Institution}

Missouri Botanical Garden, Peter H. Raven Library

\section{Sponsored by}

Missouri Botanical Garden

\section{Copyright \& Reuse}

Copyright Status: Permission to digitize granted by rights holder Rights: https://www.biodiversitylibrary.org/permissions

This document was created from content at the Biodiversity Heritage Library, the world's largest open access digital library for biodiversity literature and archives. Visit BHL at https://www.biodiversitylibrary.org. 